\title{
Six New Species of Phacelia (Hydrophyllaceae) from Arizona and New Mexico
}

\author{
N. Duane Atwood \\ Assistant Curator, Stanley L. Welsh Herbarium, Brigham Young University, Provo, \\ Utah 84602-0200, U.S.A. duane_atwood@byu.edu
}

Abstract. Six new species of Phacelia Jussieu are described from Arizona and New Mexico, U.S.A., as P. buell-vivariensis N. D. Atwood, P. cloudcroftensis N. D. Atwood, P. furnissii N. D. Atwood, P. higginsii N. D. Atwood, P. hughesii N. D. Atwood, and P. pinkavae N. D. Atwood. The new species all belong to the Crenulatae group within the genus. The new species are compared to other members of the group based on similarities and differences in stature, seed, pubescence, and leaf and flower morphology.

Key words: Arizona, conservation status, Hydrophyllaceae, New Mexico, North America, Phacelia.

This paper describes six new species of Phacelia Jussieu. The new taxa are part of voucher collections made as part of general floristic studies in Arizona, New Mexico, and Utah, and continued fieldwork on the genus in North America. They all belong to the Crenulatae group of the genus, first treated by John W. Voss in his 1937 monograph. This group is characterized by being resinous-glandular (mostly), and having 1 to 4 seeds that are somewhat cymbiform, pitted over most or all of the surface, and excavated on the ventral surface on either side of a central, longitudinal ridge. The most recent treatment of this group was by Atwood (1975). Specimens of the new taxa were compared to collections and descriptions of the 30 North American species in the Crenulatae group, including new taxa described since 1975, and the large collection of the genus at Brigham Young University (BRY).

Specimens of Phacelia pinkavae N. D. Atwood, and the name, have been in manuscript form since the early 1990s. I first collected the species in 1974 in early flower and noted the distinctive dark, glandular, mephitic pubescence, but did not recognize the uniqueness of it until additional specimens were made in 1993 and 1994. The excellent 1993 collections of the species by Jon Rebman helped to solidify the observation that the collections do indeed represent a new species. Three of the new taxa of Phacelia are from the Arizona Strip north of the Grand Canyon, where extensive fieldwork has been conducted by me and others over the past decade or so.
Phacelia cloudcroftensis N. D. Atwood and P. buellvivariensis $\mathrm{N}$. D. Atwood are more recent discoveries from farther south in Arizona and New Mexico.

In an earlier publication, in which I described Phacelia sivinskii N. D. Atwood, P. J. Knight \& Lowry (Atwood, 2005), I inadvertently failed to acknowledge for whom the species was being named. It was named in honor of Robert Sivinski, State Botanist for the Forestry Division of the New Mexico Department of Energy, Minerals, and Natural Resources Management. Bob has made, and continues to make, significant contributions to the knowledge of the flora of New Mexico. Bob has graciously provided help on several of my botanical trips to New Mexico, which I greatly appreciate.

\section{Key to Related Species in Phacelia}

la. Stamens and style included; corolla lobes denticulate.......... P. denticulata Osterhout

1b. Stamens and style exserted $1 \mathrm{~mm}$ or more; corolla lobes entire, crenulate or erose-denticulate . . . . . 2

2a. Stamens and style exserted $1-1.7 \mathrm{~mm}$; mature seeds 3 per capsule, brown, 3.6-3.9(4.3) $\times$ (1.2)1.6-1.7 mm; robust annuals, stems to $2 \mathrm{~cm}$ thick; cauline leaves rarely divided to the midrib; plants from the Sacramento Mountains, Otero Co., New Mexico....... P. cloudcroftensis N. D. Atwood

2b. Stamens and style exserted $2 \mathrm{~mm}$ or more; mature seeds 4 per capsule; stems to $1 \mathrm{~cm}$ thick and not with the above combination of characters . . . . . . 3

3a. Cauline and basal leaves strongly dissected, subbipinnatifid; corolla 3-4(5) mm long, white to lavender, broadly tubular-campanulate; lobes broadly rounded, erose-fimbriate or erose-dentate; seeds $(2) 4 \times 2.4-3.2 \mathrm{~mm}$, uniformly brown $\ldots \ldots \ldots \ldots \ldots \ldots \ldots$. . alba Rydberg

3b. Leaves not sub-bipinnatifid and strongly dissected, if dissected then not strongly so and restricted to the basal or lower cauline leaves. . . . . . . . . 4

4a. Corolla campanulate, 5.8-6.5 mm long, blue or violet; restricted to Lincoln and Clark counties (southern Nevada), northwestern Mohave Co. (Arizona), and Washington Co. (Utah) (disjunct in San Juan Co., Utah). . . . . . . . . . . . . 5

4b. Corolla tubular, tubular-campanulate, white (pale lavender) or violet, mostly less than $6 \mathrm{~mm}$ long or if over $6 \mathrm{~mm}$ long then the corolla lavender to bluish . . . . . . . . . . . . . . . 6

5a. Corolla 5.8-6 mm long, blue with a lighter tube; sepals elliptic to narrowly oblanceolate, 3-3.4(4.2) 
$\times 0.9-1.5 \mathrm{~mm}$, not enlarging in fruil; seeds excavated on each side of the ventral ridge, the ridge corrugated on one side and on the inside margins; plants of Lincoln and Clark counties (southem Nevada), northwestem Mohave Co. (Arizona), and Washington Co. (Utah) (disjunct in San Juan Co., Utah) . . . . . . . . . . . . . .

. P. petrosa N. D. Atwood, F. J. Smith \& T. A. Knight

5b. Corolla $6-6.5 \mathrm{~mm}$, violel with darker maroon veins on the lube and lobes; sepals narrowly obovate to spalulate, $2.5-2.8 \times 0.5-0.8 \mathrm{~mm}$ wide, to $5-$ $6 \mathrm{~mm}$ long in fruit: seeds flattened ventrally and essentially lacking excavations and corrugations; plants known only from northwestern Mohave Co., Arizona ............. P. furnissii N. D. Alwood

6a. Corolla tubular-campanulate, lavender, 5-6.5 mm long and broad; mature seeds oblong-elliptic, 3.1$4.5 \times 1.7-2.2 \mathrm{~mm}$, lacking corrugations on the margins and ridge, transversely ridged dorsally, the ventral ridge prominent and curved to one side; restricted to deep sandy soils; widely distributed species from southeastern Utah to Texas and Mexico .......P. integrifolia Torrey ex S. Watson

6b. Corolla tubular or tubular-campanulate, $6 \mathrm{~mm}$ long or less, white, violet, lavender, or hluish and not with the above combination of characters; plants of volcanic, limestone, or clay soils; more restricted in distribution in Arizona and New Mexico........ 7

7a. Mature seeds dark hrown; corolla light violed or bluish, 3-5 $\times 2-3 \mathrm{~mm}$; pubescence of stems and leaves densely covered with light reddish, yellowish, or black slipitate glands; plants restricted to volcanic pumice on the volcanic cones north of Flagstaff, Coconino Co., Arizona, or Buell Park. Apache Co., Arizona . . . . . . . . . . . . 8

7b. Mature seeds back; corolla white or pale violet or pale lavender, $4.2-6.5 \mathrm{~mm}$ long; plants mosily more northem in distribution except $P$. pinkavae from eastern Apache Co., Arizona, and Catron. Sandoval, and Santa Fe counties, New Mexico .... 9

8a. Stems reddish, densely retrorsely puberulent and with yellowish sessile and stipitate glands; lacking setose to hirsule hairs: sepals $2.2-2.5 \times 1-$ $1.1 \mathrm{~mm}$; seeds $2.5-2.6 \times 1 \mathrm{~mm}$, oblong to narrowly lanceolate, lacking corrugations except a few faint waves on the ventral ridge, the margins not involute........P. buell-vivariensis N. D. Alwood

8b. Stems light green to black, with retrorsely puberulent, black to dark red sessile and stipitate glands, and longer setose to hirsule hairs; sepals 3$4 \times 0.7-1.5 \mathrm{~mm}$; seeds $2.5-3.4 \times 2-2.5 \mathrm{~mm}$, elliptic-oblong, corrugated on the involute margins and one side of the ridge ......P. serrata J. W. Voss

9a. Plants densely covered with short and long black multicellular capitate glands and short nonglandular hairs; fruiting sepals ca. Iwice as long as the capsule: plants of northeastern Arizona and northwestern New Mexico ... . . . P. pinkawae N. D. Alwood

9b. Plants lacking black slipitate glands; sepals shorter to a little longer than the capsule: plants of western Colorado, northern Arizona, southcentral and southern Utah, and Clark Co., Nevada. . 10

10a. Robust, malodorous plants (2).5.3-9.8 dm tall. densely glandular with slipitate glands; leaves relatively broad, the lower the largest, to $10(13) \times$ $4 \mathrm{~cm}$; lhe cauline $2-1 \times$ longer than broad . . . . . I 10b. Plants less robust, sweelly odorous, $1.5-4.3 \mathrm{dm}$ tall, not as strongly glandular, densely retrorsely pubescent to hirsululous and hirsule; leaves more narrow, linear to linear-lanceolate or more broadly oblong, $1-10 \times 0.3-1.5 \mathrm{~cm}$, often revolute . . . 12

11a. Plants strongly malodorous, densely glandular throughout with sessile to stipitate glands; sepals $3-4 \times 1-1.8 \mathrm{~mm}$; stems leafy but not densely so; seeds elliplic, $2.5 \times 1.5 \mathrm{~mm}$; plants from southwestern Utah, northwestern Arizona, and southeastern Nevada......P. palmeri Torrey ex S. Watson

11b. Plants less glandular and mephitic, more hirsule: stems densely leafy on the main stem; sepals shorter and narrower, $2.2-3.2 \times 0.5-0.6 \mathrm{~mm}$; seeds ovate, $2.1-2.5 \times 1.1-1.2 \mathrm{~mm}$; plants below the Shivwits Plateau in Mohave Co., Arizona P. higginsii N. D. Atwood

12a. Herbage densely covered with sessile to 3-celled stipitate glands and short to longer simple hairs: stamens and style exserted 5-6 mm; leaves lanceolate to oblong, often broadly so, to $2.2 \mathrm{~cm}$ wide: plants of Sandoval. Cibola, and Socorro counties, New Mexico ................. P. sivinstii N. D. Atwood, P. J. Knight \& Lowry

$12 \mathrm{~h}$. Herbage hirsute to hirsululous, glands sessile or short-slipilate but lacking 3-celled stipitate glands; stamens and style exserted less than $5 \mathrm{~mm}$ : leaves more narrowly lanceolate to oblong, less than $1.5 \mathrm{~cm}$ wide: plants of Colorado or Utah. . . . . . . 13

13a. Flowers to $4.5 \mathrm{~mm}$ long with dark veins on the tube and lobes; seeds $1.9-2 \times 1.1-1.3 \mathrm{~mm}$. shortelliptic to oval: leaves various but not strongly revolute and mostly less than $3 \mathrm{~cm} x$ 2.2-4.3 mm: cymes in fruit elongating to $10 \mathrm{~cm}$ long .............. P. hughesii N. D. Alwood

13b. Flowers $5-6 \mathrm{~mm}$ long. lacking dark veins: seeds (2)2.5-2.8 $\times 1-1.2 \mathrm{~mm}$, elliptic: leaves linearlanceolate, strongly revolute, $1.5-7(10) \times$ $0.08(1.3) \mathrm{cm}$; cymes in fruit elongating $105 \mathrm{~cm}$

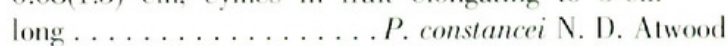

1. Phacelia buell-vivariensis N. D. Alwood, sp. nov. TYPE: U.S.A. Arizona: Apache Co., Buell Park on $\mathrm{N}$ side of Peridot Ridge, $3553.79^{\prime} \mathrm{N}$, $1095.06^{\prime} \mathrm{W}$. Navajo Indian Reservation, 5 Aug. 2004, N. D. Atwood \& A. Clifford 30555 (holotype, BRY; isotypes, ASC, ASU, BRY, CAS, GH, MO, NY, OSC, RM, US). Figure I.

Phaceliae serratae J. W. Voss pubescentia caulina pallida vel atrorubrescenti slipitato-glandulari similis, sed caulibus rubris retrorse pubescentibus trichomatibus flavescentibus stipitato-glandularibus (non setosis vel hirsutis) sepalis aliquantum brevioribus et angustioribus, $2.2-2.5 \times 1-$ $1.1 \mathrm{~mm}$ (non $1.8-3 \times 0.8-2 \mathrm{~mm}$ ) el seminibus minoribus et minus corrugatis, $2.5-2.6 \times 1 \mathrm{~mm}$ (non $3-3.2 \times 1-$ $1.3 \mathrm{~mm})$.

Annual, 2.9-4 dm tall; stems reddish, solitary or with l to 4 smaller stems from the base, densely retrosely white puberulent and glandular, the glands light reddish to yellow, sessile to short-stipitate, the stalks flat, I- to 3-celled. Leaves petiolate, petiole I- 


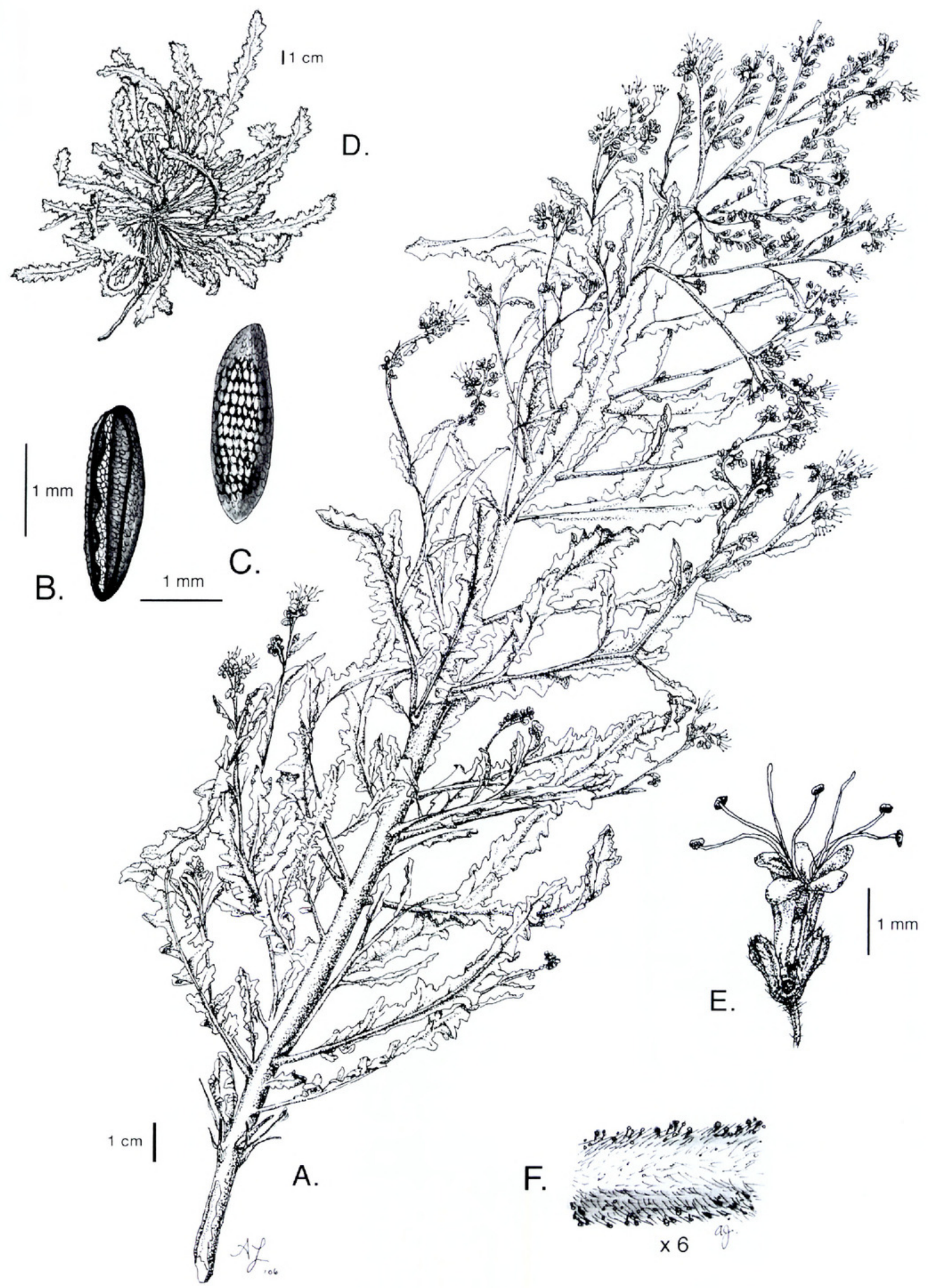

Figure 1. Phacelia buell-vivariensis N. D. Atwood. - A. Plant. - B. Ventral surface of seed. —C. Dorsal surface of seed. -D. Rosette. -E. Flower. -F. Stem pubescence. Drawn from the type collection, N. D. Atwood \& A. Clifford 30555 (BRY).

$3 \mathrm{~mm}$, the basal ones to $1 \mathrm{~cm}$; blades linear to oblonglanceolate, pinnatilobate or irregularly lobed, 1$8 \times 0.2-1.5 \mathrm{~cm}$, the margins sometimes involute, reduced upward, some basal leaves pinnately com- pound, dorsal surface scabrous-hispid and stipitateglandular, ventral surface also densely stipitateglandular. Inflorescence terminal on the short lateral branches and main stem, puberulent and with coarser, 
more densely yellowish stipitate glands than the stem: cymes 1- to 15-flowered, 1.1-3 cm; sepals in flower elliptic $2.2-2.5 \times 1-1.1 \mathrm{~mm}$, in fruit $3.5-4 \times$ $1.3-2 \mathrm{~mm}$, densely short stipitate-glandular; corolla tubular to tubular-campanulate, $4 \mathrm{~mm}$, violet or blue. pubescent on the lobes; stamens and style exserted 2-4 mm, anthers bronze, filaments violet. Capsules oblong, $2.8-3.5 \times 2 \mathrm{~mm}$, shorter to \pm equal to the sepals, finely stipitate-glandular and puberulent; mature seeds $2.5-2.6 \times 1 \mathrm{~mm}$, oblong to narrowly lanceolate, brown, excavated on both sides of the ventral ridge, one side of the ventral ridge very lightly corrugated, the margins entire, dorsal surface finely pitted.

Etymology. Phacelia buell-vivariensis is named for Buell Park, the type locality.

Relationships. The new species is related to Phacelia serrata but differs in having red stems with retrorse puberulent hairs and short yellowish stipitate glandular hairs but without setose to hirsute hairs; $P$. buell-vivariensis resembles $P$. serrata in having light to reddish black stipitate glandular pubescence on the stems. Phacelia buell-vivariensis also has somewhat different sepals $(2.2-2.5 \times 1-1.1 \mathrm{~mm}$ vs. $1.8-3 \times$ $0.8-2 \mathrm{~mm})$ and smaller, nearly noncorrugated seeds $(2.5-2.6 \times 1 \mathrm{~mm}$ vs. $3-3.2 \times 1-1.3 \mathrm{~mm})$. One side of the ridge is somewhat wavy with no distinct corrugations on the margins and ridge as in $P$. serrata.

Distribution and habitat. It is known only from the type locality in Buell Park. Apache Co., Arizona, on volcanic pumice in a Juniperus monosperma (Engelmann) Sargent, Pinus ponderosa Douglas ex C. Lawson \& G. Lawson, Bouteloua gracilis (Kunth) Lagasca ex Griffiths, and Artemisia campestris I.. community at $7191 \mathrm{ft}$. elevation.

Conservation status. The Nature Conservancy global and state rarity ranking for this species should be GISl, based on the single known occurrence.

2. Phacelia cloudcroftensis N. D. Atwood, sp. nov. TYPE: U.S.A. New Mexico: Otero Co., Sacramento Mtns., rd. cut 3.5 mi. W of Clouderoft on Hwy. $82 \mathrm{~W}$ of Jct. 82/130, $3257.59^{\prime} \mathrm{N}$, $105^{\circ} 46.47^{\prime} \mathrm{W}, 22$ July 2003, N. D. Atwood \& B. Furniss 29680 (holotype, BRY; isolypes, ASU, BRY, CAS, GH, MO, NMC, NY, RM, SJNM, UNM). Figure 2 .

Phaceliae denticulatae Osterhout habitu similis, sed caulibus robustioribus elatioribus, cymis virgatis sub fructescentia longioribus, staminibus et stylis exsertis, sepalis longioribus et latioribus, $1.5-2.5 \mathrm{~mm}$ latis (non $0.8-0.9 \mathrm{~mm}$ latis) el seminibus majoribus el latioribus, uniformiter lacunosis, crista ventrali magis corrugatis differt.
Plants to $4.7 \mathrm{dm}$ tall; stems densely covered with short retrorse appressed to spreading simple hirsute hairs, short to long, dark red to black, 1- to severalcelled capitate-glandular hairs. Cauline leaves broadly lanceolate, $3.8-10 \times 1.4-4.6(5.5) \mathrm{cm}$, irregularly crenate-dentale or lobed, densely pubescent with dark stipitate to sessile glands and hirsute hairs especially on the veins and leaf margins, the lower and basal leaves deeply lobed to pinnatifid. Inflorescence in terminal cymes on the main stem and lateral branches, densely glandular and hirsute, cymes 2 or 3 on lateral branches, more crowded and dense on the upper main stem, cymes elongating to $8.5-15 \mathrm{~cm}$ in fruit; corolla tubular, ca. 4-4.5 mm, lobes crenate to erose-denticulate, $1 \mathrm{~mm}$; stamens and style exserted $1-1.7 \mathrm{~mm}$, style bifid $3 / 4$ its length, hispidulous from the base to above the forks; calyx divided to within $1 \mathrm{~mm}$ of the base, lobes densely glandular and hirsute, unequal, linear to oblanceolate, $2.5-3.5 \mathrm{~mm}$ in flower, to $5 \mathrm{~mm}$ in fruil, $1.5-2.5 \mathrm{~mm}$ wide in fruil, longer than the capsule, the midnerve keeled. Capsule oblong. 4.5-5 mm, densely short-glandular and selulose; seeds 3, dark brown, 3.6-3.9(4.3) $\times$ (1.2) $1.6-1.7 \mathrm{~mm}$, shallowly excavated from the upturned margins, uniformly pitted, ridge usually corrugated on one side.

Elymology. Phacelia cloudcrofiensis is named for the lown of Clouderoft in the Sacramento Mountains.

Relationships. Phacelia cloudcrofiensis is most closely related to $P$. denticulata in general habit, seed characters, and the somewhat virgate thinner (to $1 \mathrm{~cm}$ thick), usually weaker stems. However, $P$. cloudcrofiensis is much more robust with stronger stems to $2 \mathrm{~cm}$ thick, longer fruiting cymes to $15 \mathrm{~cm}$ in fruit (vs. to $10 \mathrm{~cm}$ ), the ventral ridge of the seeds more corrugated, and broader fruiting sepals $(1.5-2.5 \mathrm{~mm}$ wide vs. $0.8-0.9 \mathrm{~mm}$ wide). The new species has exserted stamens and style versus the included stamens and style of $P$. denticulata. The new species also has some relationship to $P$. alba in having exserted stamens and style and erose to erosedenticulate corolla lobes versus denticulate corolla lobes, but differs in having larger seeds (3.6-4.3 $\times$ $1.2-1.7 \mathrm{~mm}$ vs. $4 \times 1.7 \mathrm{~mm})$ and more virgate and thicker stems to $2 \mathrm{~cm}$ thick (vs. stems $\leq 1 \mathrm{~cm}$ thick). It differs from both of these species in the very broad, irregularly crenate to dentate, broadly lanceolate simple cauline leaves versus smaller, more delicate, pinnately to bipinnately divided mid to upper cauline leaves.

Distribution, habital, and phenology. The first and only collection known of Phacelia cloudcroftensis, with the exception of the type material, was made by Helen 


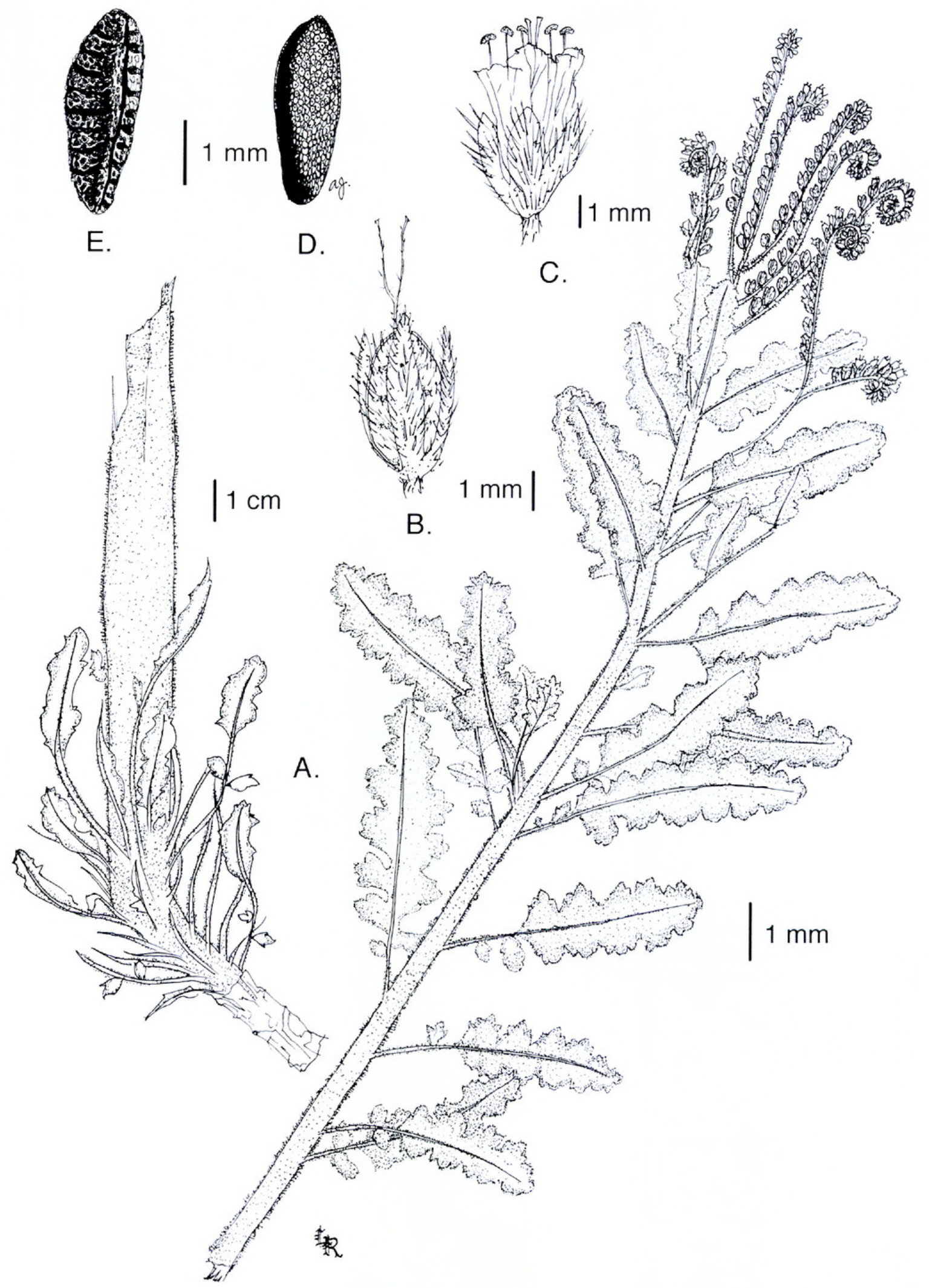

Figure 2. Phacelia cloudcroftensis N. D. Atwood. - A. Plant. - B. Fruit. - C. Flower. -D. Dorsal surface of seed. —E. Ventral surface of seed. Drawn from the type collection, N. D. Atwood \& B. Furniss 29680 (BRY).

Bobisud in the 1960s. The Bobisud collection was part of material borrowed from herbaria in the southwestern United States to gain a better understanding of $P$. integrifolia and related taxa. The specimen had been identified as $P$. integrifolia, a name that has been loosely used incorrectly for numerous collections. The new species is presently known only from 3 to 3.5 miles west of Cloudcroft, 
New Mexico, along U.S. Hwy. 81. Flowering July-late September, or probably even into October.

Conservation status. The Nature Conservancy global and state rarity ranking for this species should be GISI, based on the two small populations of only a few individual plants.

Paralypes. U.S.A. New Mexico: Otero Co., 3 mi. W of Clouderoft on U.S. 82, 31 July 196?, Helen Bubisud 1.32 (BRY |xerograph], UNM): 3.8 mi. W of Clouderoft on Hwy. 82, T15S, R13E, SI, 7 Sep. 2002, N. D. Atwood 29003 (BRY, K, NMC, RSA, UNM).

3. Phacelia furnissii N. D. Atwood, sp. nov. TYPE: U.S.A. Arizona: Mohave Co., Arizona Strip, Grand Canyon-Parashant National Monument, Andrus Canyon at rd. crossing, T32N, R10W, S6 \& 7, 27 May 2003, N. D. Atwood \& L. C. Higgins 29469 (holotype, BRY; isotypes, ARIZ, ASU, BRY [5], K, MO, NY, OSC, RM, TEX, UNLV, UNM, US). Figure 3.

Phaceliae petrosae N. D. Atwood, F. J. Smith \& T. A. Knight affinis, sed caulibus saepe magis virgatis, robustioribus et elatioribus, floribus majoribus pallide violaceis, in tubo el lobis venis atropurpureis, capsulis minoribus el seminibus et foliis differt.

Tall robust annual or possible winter annual, producing basal leaf rosettes in the late summer or fall after the first rains; stems solitary or few branches from the base, more often with numerous lateral branches to $2.8 \mathrm{dm}$, leafy flowering branches to just below the terminal part of the main stem inflorescence, $3.2-8 \mathrm{dm}$ tall, densely glandular with short to long l-celled or multicellular reddish to black stipitate glands. Basal rosette of leaves deeply sinuate to pinnatifid, oblong, persisting into the fruiting stage, densely covered with stipitate-glandular hairs as on the stem, ventral surface also with pustulate setose to hispid pubescence, less so on the dorsal surface, $4-11 \times 1.5-2.5 \mathrm{~cm}$, petiolate, petiole to $4 \mathrm{~cm}$; cauline leaves to ca. the middle of the stem and mostly lacking in the inflorescence, crenate to irregularly lobed mostly less than $1 / 2$ the way to midrib, broadly lanceolate, densely stipitate-glandular. Inflorescence densely flowered, of lateral and terminal cymes, cymes terminating lateral branches solitary or in pairs, the terminal cyme group of the main stem 8-20 cm long, each cyme mostly single and alternate, not paired, individual cymes $1-4 \mathrm{~cm}$ in flower, elongating to $8 \mathrm{~cm}$ in fruit, densely stipitateglandular; flowers campanulate, $6-6.5 \mathrm{~mm}$, pale violet with darker maroon veins on the tube and lobes, pedicellate, pedicel $0.5 \mathrm{~mm}$ in flower, lobes ca. $2 \mathrm{~mm}$ broad and often puberulent and glandularstipitate; calyx lobes narrowly obovate to spatulate,
$2.5-2.8 \times 0.5-0.8 \mathrm{~mm}$, with black stipitate-glandular and hirsute hairs in flower, 5-6 mm in fruit, the midrib raised; fruiting pedicels ca. $1 \mathrm{~mm}$; stamens and style exserted $4-5.5 \mathrm{~mm}$, style forked to ca. the middle and pubescent to the forks, filaments violet, anthers bronze. Capsules 3.4-3.5 × 2.5 mm, oblong, glandular dotted and appressed setulose; seeds brown, oblong, flattish ventrally on each side of the prominent ridge and essentially lacking the typical excavations on either side of the ridge, coarsely pitted on each side of the ridge, pitling on the ridge smaller, dorsal surface slightly rounded, pitted, faintly cross-corrugated, $3-3.4 \times 1.2-1.4 \mathrm{~mm}$.

Etymology. Phacelia furnissii is named for Blaine Furniss of Brigham Young University, who has provided valuable assistance on numerous field trips, including collection of several of the paratypes.

Relationships. Phacelia furnissii is allied to $P$. petrosa but differs from that species in the often more virgate, robust, and taller stems $(3.2-8 \mathrm{dm}$ vs. $1-3.6 \mathrm{dm}$ ), larger pale violet flowers with dark maroon veins on tube and lobes (vs. blue corolla with a lighter tube and base), smaller capsules (3.4-3.5 $\times 2.5 \mathrm{~mm}$ vs. $4-4.3 \times 3-3.3 \mathrm{~mm}$ ) and different seed (oblong flattish, corrugated and pitted ventrally from the edge to the ridge on each side, the ridge low and essentially lacking the typical excavations on either side, dorsal surface slightly rounded, faintly cross-corrugated, $3-3.4 \times 1.2-1.4 \mathrm{~mm}$ vs. seeds deeply excavated with longer and narrower pitting, corrugations only on one side of the prominent ridge and margins, $3.3-3.8 \times 1.5-3.1 \mathrm{~mm})$, and leaf morphology.

Distribution, habitat, and phenology. At the type locality in Andrus Canyon, Phacelia furnissii occupies habitat in association with six other species of Phacelia-P. petrosa, P. pedicellata A. Gray, P. ambigua M. E. Jones, P. glechomaefolia A. Gray, P. coerulea Greene, and $P$. rotundifolia Torrey ex $S$. Watson. Each species is easily distinguished from each other with no apparent hybrids. Of the species present, it appears to be most closely related to $P$. petrosa. At the other known sites, it is the primary species in the habitat where it has been collected (i.e., Hack, Whitmore, and Parashant canyons of northwestern Mohave County, Arizona. It flowers in April and May, and apparently has a longer period for development of mature seeds, into September or early October. It is easily distinguished, especially in flower, by its large, 5-6 mm long, pale lavender flowers with the dark maroon veins on the tube and limbs. The terminal group of cymes are $8-20 \mathrm{~cm}$ long.

It occurs in limestone gravels and boulders of wash bottoms and steep limestone talus of desert 


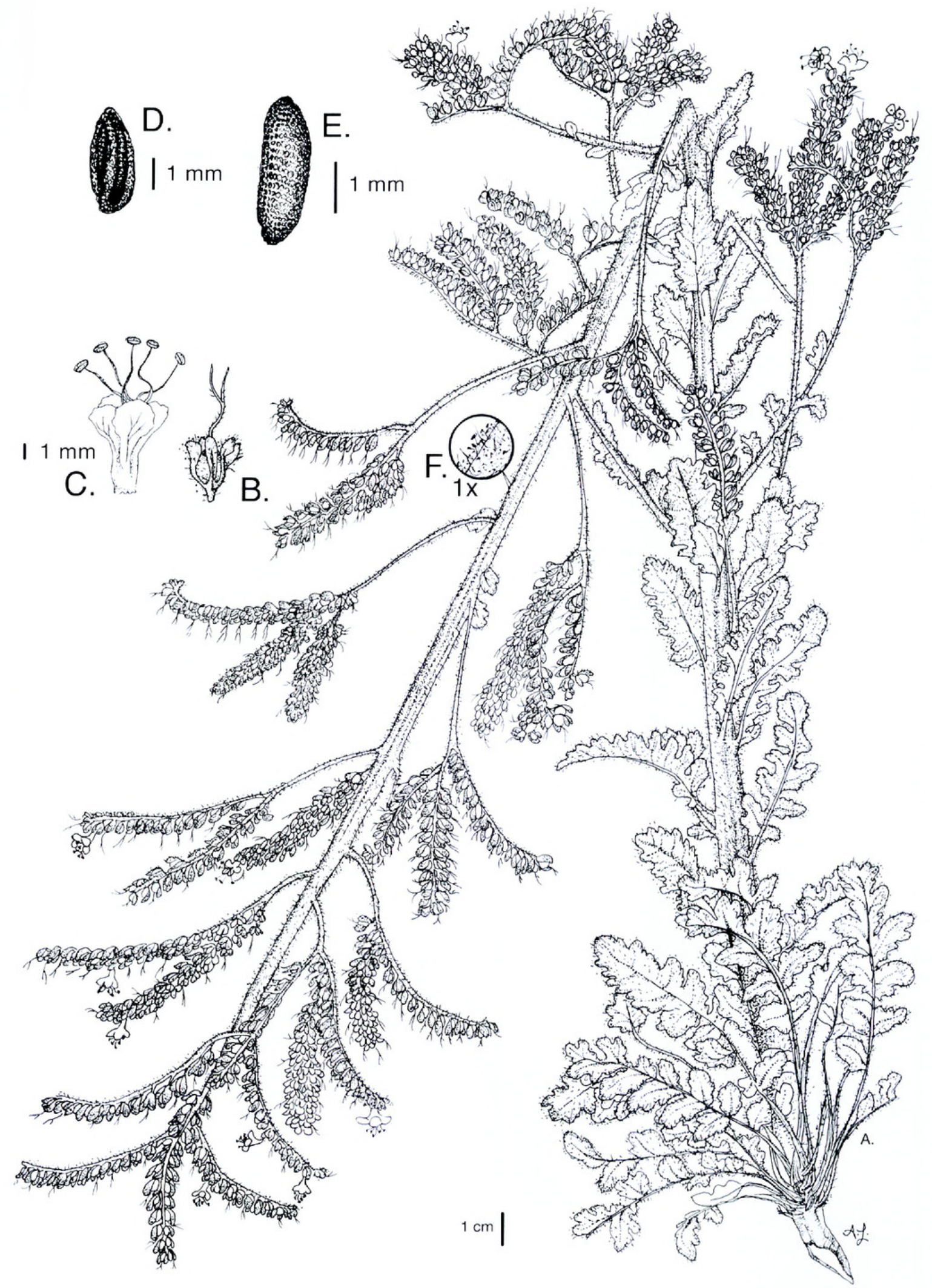

Figure 3. Phacelia furnissii N. D. Atwood. - A. Plant. - B. Fruit. - C. Flower. - D. Ventral surface of seed. —E. Dorsal surface of seed. -F. Stem pubescence. Drawn from the type collection, N. D. Atwood \& L. C. Higgins 29469 (BRY).

shrub communities with Fraxinus anomala Torrey ex S. Watson, F. cuspidata Torrey var. macropetala (Eastwood) Rehder, Berberis fremontii Torrey, Ptelea trifoliata L., Bernardia incana C. V. Morton, Rhus trilobata Nuttall, Fallugia paradoxa (D. Don) Endlicher ex Torrey, Atriplex canescens (Pursh) Nuttall, Gutierrezia microcephala (DC.) A. Gray, scattered Juniperus monosperma, Pinus edulis Engelmann in 
Wislizenus, and Stipa speciosa Trinius \& Ruprecht at 3681-4600 ft. (1100-1400 m) elevation.

Conservation slatus. The Nature Conservancy global and state rarity ranking for this species should be GIS2, based on the limited distribution.

Paralypes. U.S.A. Arizona: Mohave Co., Arizona Strip, Grand Canyon-Parashant National Monument (GCPNM), T33N, R12W, S17 W of Andrus Canyon, 19 Apr. 2000, N. D. Atwood, L. C. Higgins \& B. Furniss 25062 (BRY); GCPNM, T33N, R12W, S26, 19 Apr. 2000, N. D. Alwood, L. C. Higgins \& B. Furniss 25078 (BRY); GCPNM, 4 mi. down Andrus Canyon, T33N, R12W, S26, 19 Apr. 2000, N. D. Atwood, L. C. Higgins \& B. Furniss 25084 (BRY); GCPNM, Trail Canyon at rd. T32N, R10W, S6 \& 7 at rd. crossing, 19 Apr. 2000, N. D. Atwood, L. C. Higgins \& B. Furniss 25097 (BRY): GCPNM, Andrus Canyon, T33N, R12W, S26, 19 Apr. 2000, N. D. Anood, L. C. Higgins \& B. Furniss 25084 (BRY): GCPNM, Andrus Canyon above rd. crossing. II Oct. 2000, N. D. Atwood 26249 (BRY); GCPNM, ca. 7 mi. down Parashant Canyon from Trail Canyon summit, 11 Oct. 2000. N. D. Atwood 26279 (BRY); GCPNM. Andrus Canyon, T32N, RIOW, S7NWNW, 17 Apr. 2003, N. D. Alwood \& L. C. Higgins 29158 (BRY [2], CPH, DAV, FSU, GH, MU, NLU, RSA, SRP, UNLV); GCPNM, Andrus Canyon, T32N, R10W, Sl8NE1/4, 17 Apr. 2003, I. C. Higgins \& N. D. Atwood 24366 (BRY, Dixie State College, UNIV): GCPNM, Andrus Canyon, 1-4 mi. above rd. crossing, T32N, R1IW, SI, 24, 25 \& 36, 27 May 2003, N. D. Atwood 29478 (ARIZ, ASU. BM, BRY, K. MO, NMU, NY, OSC, RM, TEX, UNM, US); bottom of Trail Canyon, T33N, RIOW, SIINEI/4, 27 May 2003, N. D. Anood \& L. C. Higgins 29495 (ARIZ, ASC, ASU, BU, BRY [2], K, NY, MO, OSC, RM, RSA, SISC, TAES, TEX. UNM, US, WIS); GCPNM, Andrus Canyon, T32N, R10W, S17, 27 May 2003, L. C. Higgins \&. N. D. Atwood 24593 (BRY, Dixie State College): GCPNM, Whitmore Wash, $36^{\circ} 12.23^{\prime} \mathrm{N}, 11318.25^{\prime} \mathrm{W}, 3$ Sep. 2003, N. D. Alwood. B. Furniss \& L. C. Higgins 29727 (BRY); GCPNM, in small side draw in Parashant drainage, $36^{\circ} 12.23^{\prime} \mathrm{N}, 11318.25^{\prime} \mathrm{W}, 18$ Sep. 2003. N. D. Atwood 29892 (BRY): GCPNM, bottom of Trail Canyon, $3616.72^{\prime} \mathrm{N}, 11320.00^{\prime} \mathrm{W}, 26 \mathrm{Apr} .2004, \mathrm{~N}$. D. Alwood 30119 (ARIZ, ASC, ASU, BM, BRY |2|, CAS, K, NY, RM, RSA, UNLV); GCPNM, Andrus Canyon, T32N, Rlow, 27 Apr. 2004, N. D. Atwood \& I. C. Higgins 30136 (BRY |2|, UNIV): GCPNM, Andrus Canyon, T32N. R10W, S21, 27 Apr. 2004, L. C. Higgins \& N. D. Atwood 25325 (BRY, Dixie State College): GCPNM, Parashant Canyon, T33N, R10W, S11, 28 Apr. 2004, L. C. Higgins \& N. D. Atwood 25365 (BRY): GCPNM, bottom of Trail Canyon, T33N, RIOW, S2, 28 Apr. 2004, L. C. Higgins \& N. D. Atwood 25382 (BRY, Dixie State College, UNLV); Kanab Plateau BLM administered lands. Hack Canyon $4 \mathrm{mi}$. down canyon from pond. $3635.90^{\prime} \mathrm{N}$. $112^{2} 49.33^{\prime} \mathrm{W}, 11$ May 2004, N. D. Alwood 30188 (BR) [4], CAS, MO, OSC, RSA, TAES, UNIV, WIS): Kanab, Plateau BLM administered lands, 2 mi. down Hack Canyon, T37N, R5W, S22, 11 May 2004, N. D. Alwood 3019 (ARIZ, ASU, BRY [2]. NMC, UNIV. UTC): Kanab Plateau BL.M administered lands, Hack Canyon, T37N, R.5 W. S20, 14 May 2004, L. C. Higgins 25538 (ASC, BRY [2], Dixie State College, TEX).

4. Phacelia higginsii N. D. Atwood, sp. nov. T'YPE: U.S.A. Arizona: Mohave Co., Arizona Strip.
$12.5 \mathrm{mi}$. SW from head of Trail Canyon toward Andrus Canyon, $36^{\circ} 11.48^{\prime} \mathrm{N}, 113^{\circ} 19.10^{\prime} \mathrm{W}, 3$ Sep. 2003, N. D. Atwood, B. Furniss \& L. C. Higgins 29729 (holotype, BRY; isotypes, ARIZ, ASU, BM, BRY [3], Dixie State College, K, MO, NY, RM, TEX, US). Figure 4.

Phaceliae palmeri Torrey ex S. Watson habitu similis. sed herba minus viscida el mephitica, hirsutiore, interdum perenni (non semper bienni), densius foliata, sepalis brevioribus el angustioribus, $2.2-3.2 \times 0.5-0.6 \mathrm{~mm}$ (non $4-5 \times$ $1-1.8 \mathrm{~mm}$ ), corollis tubulari-campanulatis violaceis (non violascentibus vel albis), et seminibus minoribus, $2.1-2.5 \times 1.1-$ $1.2 \mathrm{~mm}($ non $2.5 \times 1.5 \mathrm{~mm})$ differt.

Perennial or more commonly biennial plants with 1 or sometimes 2 virgate stems (3.5)5.3-9.8 dm tall, leafy with few to numerous short lateral branches to $13 \mathrm{~cm}$ long, stem pubescence with a dense mix of spreading short and longer hirsute simple hairs, short-stipitate glands and some longer flattened 2-celled stipitateglandular ones. Cauline leaves lanceolate to ovate, mostly flat or somewhat revolute on some plants, $1.5-9 \times 0.5-2 \mathrm{~cm}$, hirsute and with short spreading capitate glands on both surfaces, regularly to irregularly crenate-dentate, petiolate, petiole $0.5-2 \mathrm{~cm}$; basal rosette prostrate, to $3 \mathrm{dm}$ broad, developing early and withering before flowering, leaves 9-13 $\times 1.5-3 \mathrm{~cm}$, irregularly crenate to dentate or pinnatifid, dorsal surface densely hirsute, ventral surface with short and longer hirsute pubescence especially on the midrib and veins, petiolate, petiole to $4 \mathrm{~cm}$. Inflorescence of compound cymes densely arranged along the stem on the terminal part of each lateral branch, cymes 1 to 3, $1-5 \mathrm{~cm}$ long in flower, $1010 \mathrm{~cm}$ in fruit, densely pubescent with a mix of 1 - to 4-celled flattened stipitate-glandular hairs and a few long hirsute and small simple hairs; flowers tubular-campanulate, violet, 4.5-5 mm, some of the lobes often pubescent; stamens and style exserted $3.5-5 \mathrm{~mm}$; style bifid $2 / 3$ its length, pubescent to the forks; filaments violet, anthers bronze; calyx lobes narrowly oblanceolate-spatulate or elliptic, shorter than the flowers, densely stipitate-glandular and hirsute especially on the margins, ribs on the dorsal surface of sepals elevated or ribbed, $2.2-3.2 \times$ $0.5-0.6 \mathrm{~mm}$ in flower, $4.5-4.8 \times 1-1.7 \mathrm{~mm}$ in fruit, and longer than the capsule. Capsules oval, 2.5 $2.7 \times 2.2-2.5 \mathrm{~mm}$, with short stalked glands and spreading to ascending hirsute pubescence; seeds 4 , black, ovate, boat-shaped, excavated ventrally, 2.1$2.5 \times 1.1-1.2 \mathrm{~mm}$, the margins and ridge corrugated, the dorsal surface pilted and lightly cross-corrugated.

Etymology. Phacelia higginsii is named in honor of Larry C. Higgins, who has made a significant contribution to the Arizona Strip flora and assisted in collection of the type collections. 

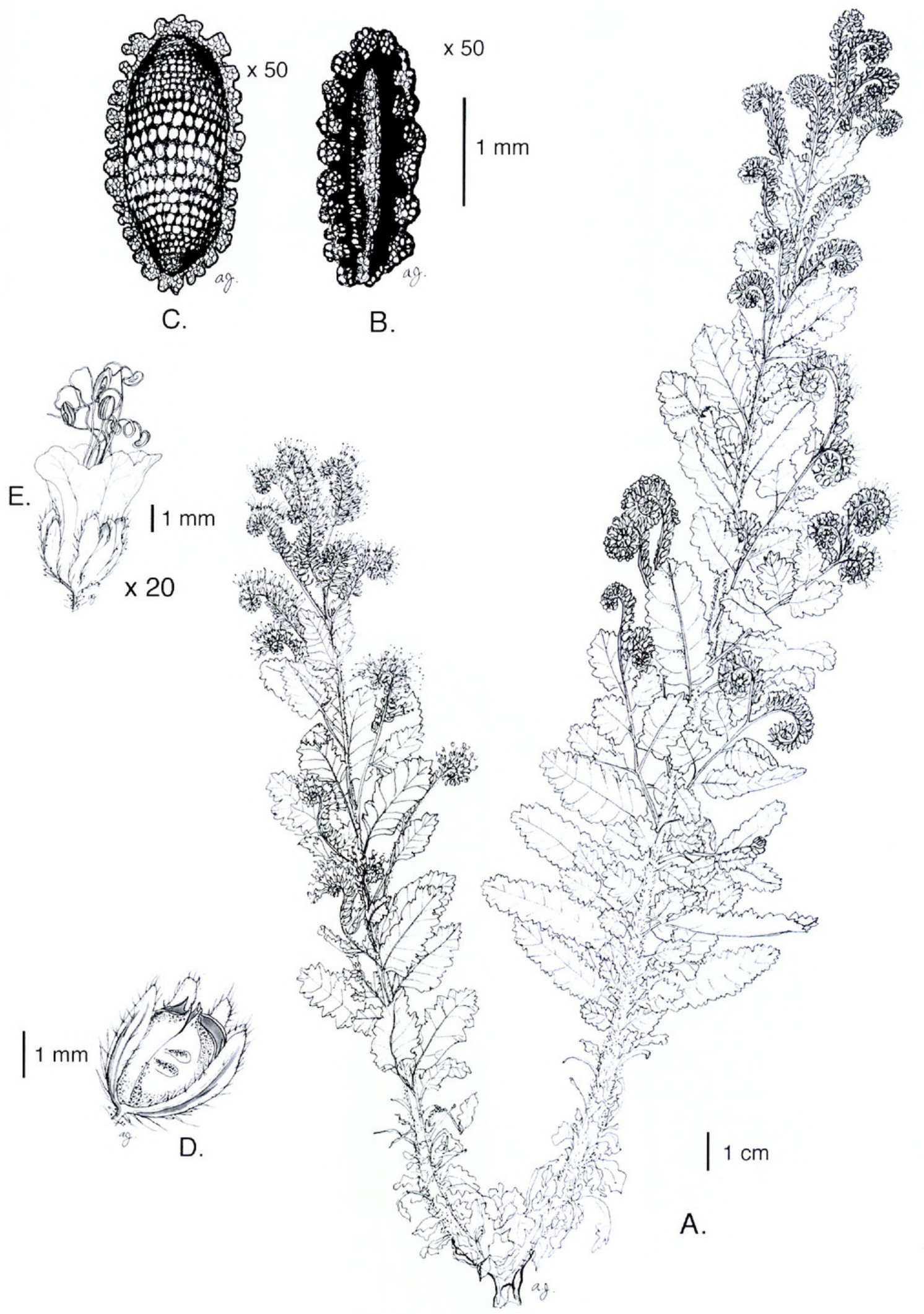

Figure 4. Phacelia higginsii N. D. Atwood. - A. Plant. - B. Ventral surface of seed. —C. Dorsal surface of seed. -D. Fruit. -E. Flower. Drawn from the paratype collection, N. D. Atwood 29892 (BRY).

Relationships. Phacelia higginsii is similar to $P$. palmeri in general habit but is less viscid and mephitic, is sometimes perennial in habit (vs. always biennial in P. palmeri), is more densely leafy on the main stem, has shorter and narrower sepals $(2.2-3.2 \times 0.5-0.6 \mathrm{~mm}$ vs. $4-5 \times 1-1.8 \mathrm{~mm}$ ), has tubular-campanulate corollas (vs. tubular corollas), and has smaller seeds (2.1$2.5 \times 1-1.2 \mathrm{~mm}$ vs. ca. $2.5 \times 1.5 \mathrm{~mm})$. 
Distribution, habitat, and phenology. Phacelia higginsii occupies habitat below the Uinkaret and Shivwits Plateau in and between the Whitmore, Parashant, and Andrus Canyon drainages west of Mount Trumbull, in Mohave County, Arizona. Associated plant species are more typical of the Mohave Desert. Phacelia higginsii also differs in phenology from $P$. palmeri, with the seeds germinating in the fall or spring, depending on available moisture, and producing a biennial rosette or a rosette from the surviving root stock of the previous year. The rosette remains green through the winter and summer, storing food reserves through these seasons and producing a flowering stem in late summer or fall, depending on the availability of moisture in any given year. Mature seeds are produced in September-October. Phacelia palmeri is a much earlier-flowering species, starting as early as mid to late March and producing mature seeds in late April-June. It occurs on red clay and limestone outcrops in canyon bottoms and open slopes of desert shrub communities with Yucca vespertina (McKelvey) S. L. Welsh, Ephedra L., Mortonia scabrella A. Gray, Brickellia longifolia S. Watson. Acacia Miller, Krameria parvifolia Bentham, Coleogyne ramosissima Torrey, Sporobolus cryptandrus A. Gray, Eriogonum heermannii Durand \& Hilgard var. sulcatum (S. Watson) Munz \& Reveal, Ambrosia confertiflora DC., Mentzelia pumila (Nuttall) Torrey \& A. Gray, Datura wrightii Regel, and Chrysothamnus Nuttall at $3532-3793 \mathrm{ft}$. (1072-1158 m) elevation in Mohave County, Arizona, north of the Grand Canyon.

Conservation status. The Nature Conservancy global and state rarity ranking for this species should be GISl, based on the limited range and number of individuals present in the habitat.

Paratypes. U.S.A. Arizona: Mohave Co., Arizona Strip, Grand Canyon-Parashant National Monument, Andrus Canyon above rd. crossing, T32.5N, R11W, Sl, $11 \mathrm{Oct}$. 2000, N. D. Atwood 26249 (ARIZ, ASU, BRY); 7 mi. down Parashant Canyon from summit of Trail Canyon, T33N, R9W. S31, II Ocl. 2000, N. D. Alwood 26279 (BRY, MO, NY. RM): Whitmore Canyon, $3612.23^{\prime} \mathrm{N}, 113^{\prime} 18.25^{\prime} \mathrm{W}, 3 \mathrm{Sep}$. 2003, N. D. Atwood, B. Furniss \& I. C. Higgins 29727 (ARIZ, ASC, BM, BRY [3], CAS, GH, K, MNA, MO, NY. OSC, RM, RSA, SP, TEX, UC, UNM, US); Parashant drainage in small side canyon $W$ of trail, $3612.23^{\prime} \mathrm{N}$. $113^{\circ} 18.25^{\prime} \mathrm{W}, 18$ Sep. 2004. N. D. Atwood 29892 (ASU, BRY [3], Dixie State College, MO, NY, RM, UNM). 29893 (ARIZ, BM, BRY |3|, K, MO, POM, RM, RSA, TEX. UMN).

5. Phacelia hughesii N. D. Atwood, sp. nov. TYPE: U.S.A. Arizona: Mohave Co., Arizona Strip. T34N, RIIW, S8, E of Salt Spring $S$ base of Poverty Mın., 20 Sep. 2001, N. D. Atwood \& L. E. Hughes 27814 (holotype, BRY; isotypes, ARIZ.
ASU, BRY [2], Dixie State College, MO, NY, US). Figure 5 .

Phaeliae constancei N. D. Atwood affinis sed pubescentia dense hirsutulosa vel hirsuta, non glandulari, foliis lanceolatis vena centrali ventraliter elevata, floribus et sepalis et capsulis minoribus, et seminibus parvis ovalibus et magis corrugatis differt.

Biennial, $3.2 \mathrm{dm}$ tall; stems 1 to several, reddish, freely branched, densely hirsutulous-hirsute, lacking capitate-glandular hairs. Leaves mostly cauline, lanceolate, $0.6-2.3 \mathrm{~cm} \times 2.2-4.3 \mathrm{~mm}$, somewhat revolute but not strongly so, midvein recessed dorsally and prominently raised ventrally, finely hirsutulous, short-petiolate. Inflorescence of lateral and terminal cymes, cymes elongating to $10 \mathrm{~cm}$ in fruit; sepals oblanceolate-spatulate, $2.3 \mathrm{~mm}$ in flower, $3.5-5.6 \times 1.2-1.6 \mathrm{~mm}$ in fruit, $1-2 \mathrm{~mm}$ longer than the capsule, densely hirsutulous; flowers ca. $4.5 \mathrm{~mm}$, white with purple veins on the tube and lobes, tube $3.5 \mathrm{~mm}$, pubescent externally, lobes ca. $1 \mathrm{~mm}$; stamens and style exserted 4-5 mm, anthers violet, style pubescent to above the middle. Mature seeds 4 , black, oval, 1.9-2 × 1.1-1.3 mm, short-elliptic to oval, corrugated around the edge and on one side of the ventral ridge, excavated on both sides of the ridge, pitted.

Etymology. Phacelia hughesii is named for Lee E. Hughes, ecologist for the Arizona Strip District of the Bureau of Land Management.

Relationships. Phacelia hughesii is most closely related to $P$. constancei but is distinguished from that species by the dense hirsutulous to hirsute nonglandular pubescence; small lanceolate leaves with a raised ventral midvein; smaller flowers, sepals, and capsules; and small, oval, more corrugated seeds.

Distribution and habitat. Phacelia hughesii is known only from limestone outcrops of the Harrisburg Formation on the Arizona Strip in Mohave County. Associated with pinyon-juniper, mixed desert shrub communities with Pinus edulis, Juniperus osteosperma (Torrey) Little, Chrysothamnus nauseosus (Pallas) Britton var. mohavensis (Greene) H. M. Hall, Eriogonum elatum Douglas ex Bentham, Cordylanthus parviflorus (Ferris) Wiggins, Tetradymia canescens DC., Sporobolus cryptandrus, Artemisia bigelovii A. Gray, Abronia fragrans Nuttall ex Hooker, lepidium montanum Nuttall, Gutierrezia sarothrae (Pursh) Britton \& Rusby, Oenothera caespitosa Nuttall var. stellae S. L. Welsh, Mentzelia integra (M. E. Jones) Tidestrøm, Camissonia exilis (P. H. Raven) P. H. Raven, Atriplex canescens, Yucca baccata Torrey, and Parthenium ligulatum (M. E. Jones) Barneby at 4660-5938 ft. (1423-1812 m) elevation. 


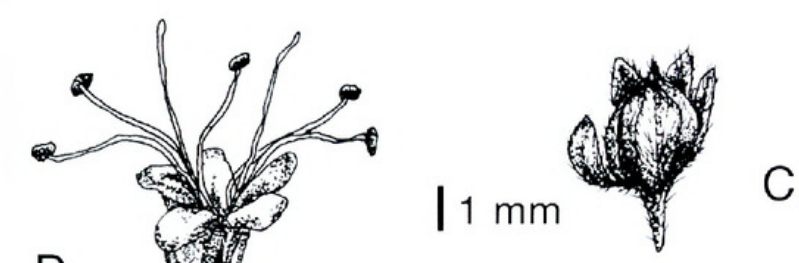

D.

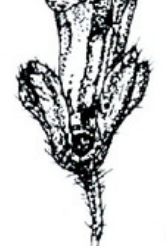

A.

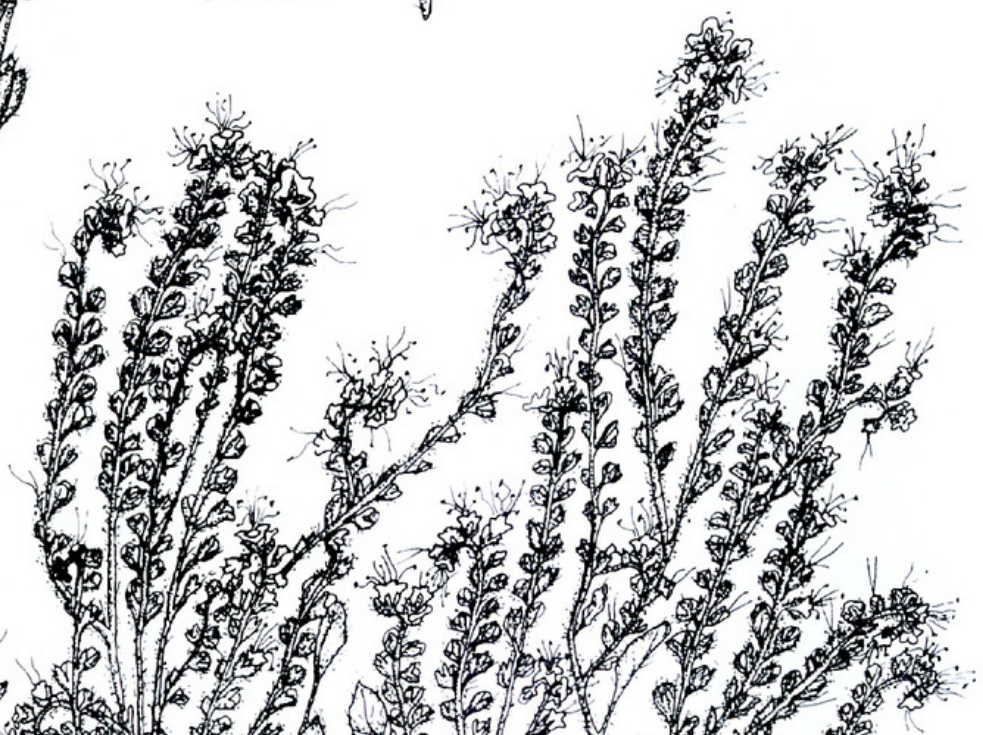

1 (1)
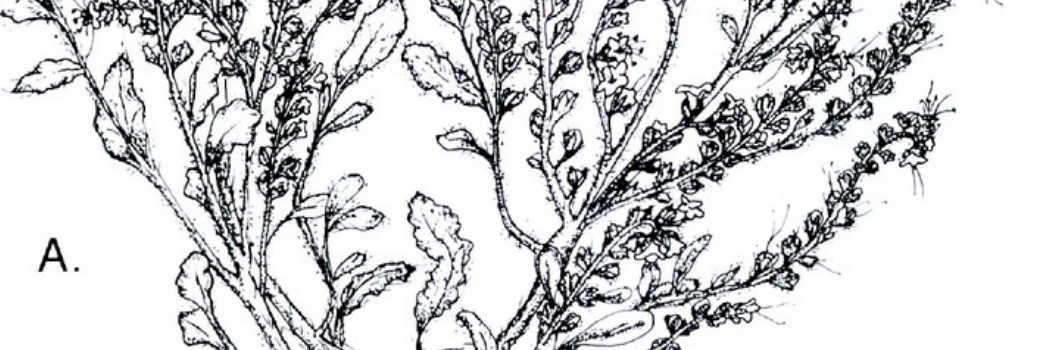

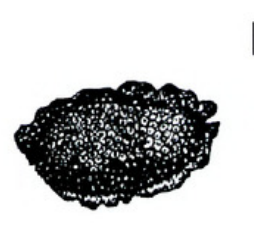

B.

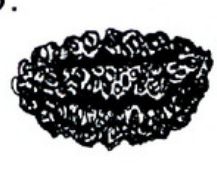

$\overline{1 \mathrm{~mm}}$
C.

$1 \mathrm{~cm}$

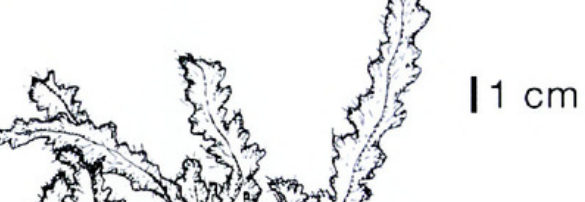

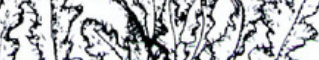
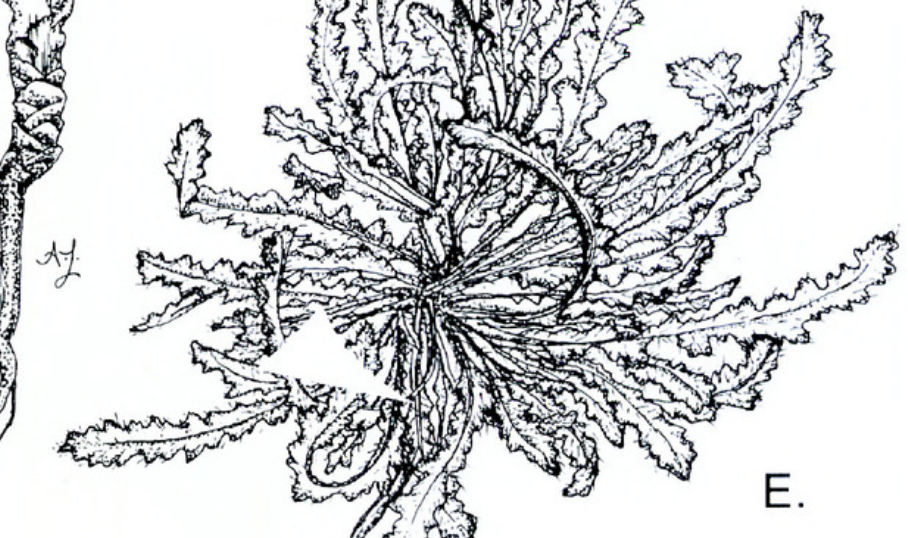

E.

Figure 5. Phacelia hughesii N. D. Atwood. - A. Plant. -B. Seed, dorsal (left) and ventral (right) views. -C. Fruit. -D. Flower. -E. Rosette. Drawn from the type collection, N. D. Atwood \& L. E. Hughes 27814 (BRY).

Conservation status. The Nature Conservancy global and state rarity ranking for this species should be G1S3, based on the number of populations and distribution.

Paratypes. U.S.A. Arizona: Mohave Co., Arizona Strip, Unikaret rd. on Temple Trail, $8 \mathrm{mi}$. S of jet. with Navajo
Trail, 2 Sep. 1977, K. Thorne 195 (BRY); ca. 2 mi. from Black Canyon on Clayhole rd., T38N, R7W, S33, 4 Sep. 1977, K. Thorne 300 (BRY); Tuweep Valley ca. 1 mi. S of Nixon Spring rd. on Tuweep Valley rd., T34N, R7W, S16, 6 Sep. 1977, K. Thorne 327 (BRY); Sandridge rd. 5 mi. S of Antelope Springs, T40N, R9W, S17, 7 Sep. 1977, K. Thorne 
336 (BRY); Hack Canyon ca. 35 mi. S of Pipe Springs, T37N, R6W, S26, $3635.39^{\prime} \mathrm{N}, 112^{\circ} 49.23^{\prime} \mathrm{W}, 15$ Oct. 2002 , R. C. Sivinsti \& B. Weber 5698 (BRY [2]); S of Colorado City Uinkaret Plateau, $36^{\circ} 49.2 \mathrm{I}^{\prime} \mathrm{N}, 113^{\circ} 10.29^{\prime} \mathrm{W}$ T40N, R8W, S32SE1/4, 20 Aug. 2003, N. D. Alwood, B. Furniss \& L. C. Higgins 29708 (BRY); S of Hal Knoll \& N of Spencer Knoll on BLM rd. 1008, $3633.40^{\prime} \mathrm{N}, 1135.05^{\prime} \mathrm{W}, 20$ Aug. 2003 , N. D. Alwood 29721 (ARIZ, ASU, BM, BRY [2], GH, K. MNA, MO, OSC, RM); on BLM rd. 1008 going W, $3631.54^{\prime} \mathrm{N} 113^{\circ} 12.95^{\prime}$ W, 20 Aug. 2003, N. D. Atwood, B. Furniss \& L. C. Higgins 29723 (BRY, MO, TEX); Hurricane Valley, $36^{\circ} 27.81^{\prime} \mathrm{N}, 11320.18^{\prime} \mathrm{W}, \mathrm{T} 36 \mathrm{~N}, \mathrm{R} 10 \mathrm{~W}, \mathrm{~S} 35,4$ Sep. 2003, N. D. Atwood, B. Furniss \& L. Higgins 29739 (BRY); SE of Diamond Butte, $3631.93^{\prime} \mathrm{N}, 113^{\circ} 21.63^{\prime} \mathrm{W}, 4$ Sep. 2003, N. D. Atwood, B. Furniss \& L. C. Higgins 29743 (ASC, BRY, CAS, NY, OSC, RSA, SP, TEX, UNM, US); head of Hack Canyon $S$ of Pipe Springs, $3636.67^{\prime} \mathrm{N}$, $11350.78^{\prime}$ W, 5 Sep. 2003, N. D. Atwood \& L. C. Higgins 29764 (BRY); W of BLM rd. 5 on rd. $1008 \mathrm{~S}$ of Hat Knoll, $3633.57^{\prime} \mathrm{N}, 113^{\circ} 4.84^{\prime}$ W. 17 Sep. 2003 , N. D. Atwood 29883 (BM, BRY [3], CAS, GH, K, MNA, MO, NY, OSC, RM, RSA, SP, TEX, UC, US); 2.5 mi. E of BI.M rd. 1008 from jet. of rd. $5,3631.67^{\prime} \mathrm{N}, 113^{\circ} 13.5 \mathrm{I}^{\prime} \mathrm{W}, 21$ Sep. 2003, N. D. Alwood 29992 (BRY |3|, CAS, UNA, SP, UC, UNM); $3.4 \mathrm{mi}$. E of rd. 1008 from jcl. with rd. $5,36^{\circ} 11.93^{\prime} \mathrm{N}, 13^{\prime} 13.01^{\prime} W, 21$ Sep. 2003, N. D. Alwood 29993 (ASC, BRY [3], RSA); WNW of rd. 1001 near old Escalante Historic Trail, $3638.28^{\prime} \mathrm{N}$. $113^{\circ} 14.23^{\prime}$ W, 22 Sep. 2003, N. D. Atwood 30035 (BRY): N of Mt. Trumbull $3635.35^{\prime} \mathrm{N}, 113^{1} 18.02^{\prime} \mathrm{W}, \mathrm{T} 37 \mathrm{~N}, \mathrm{R} 9 \mathrm{~W}$, S23, 5 May 2004, N. D. Alwood 30184 (BRY); Honeymoon Trail on BL.M rd. 1001, $36^{\circ} 37.12^{\prime} \mathrm{N}, 11313.97^{\prime} \mathrm{W}, 3$ Sep. 2004, N. D. Atwood \& A. Merkley 30667 (BRY); along BL.M rd. 1015 betw. Pipe Springs and Mt. Trumbull, 3 Sep. 2004 , N. D. Atwood \& A. Merkley 30670 (BRY, MO, NY); Uinkaret Plateau N of Temple Tank S of Antelope Knoll, T38N, R9W. S26, 3 Sep. 2004, L. C. Higgins 26112 (BRY |2|, Dixie State College); Uinkaret Plateau, T40N, R9W, S14, 3 Sep. 2004, $L$. C. Higgins 26116 (BRY, Dixie State College); rd. 1015 to Temple Trail, $3651.82^{\prime} \mathrm{N}, 11314.04^{\prime} \mathrm{W}, 2 \mathrm{l}$ Sep. 2004, N. D. Alwood 30705 (BRY, MO, NY, OSU, RM, US); BLM rd. $717 \mathrm{~N}$ of Mt. Trumbull, $3628.2 \mathrm{I}^{\prime} \mathrm{N}, 1132.80^{\prime} \mathrm{W}, 22 \mathrm{Sep}$. 2004, N. D. Alwood 30736 (ARIZ, ASU, BM, BRY, CAS, K, MNA, MO, NY, OSC, RM, RSA, SP, TEX, US); Grand Canyon-Parashant National Monument, $S$ of Poverty Mtn., T34N, RIIW, S6, 15 Sep. 2004, L. C. Higgins 26139 (BRY [2], Dixie State College).

6. Phacelia pinkavae N. D. Atwood, sp. nov. TYPE: U.S.A. Arizona: Apache Co., ca. 7 mi. N of Springerville along Hwy. 60 at Jet. 60/180 \& 666, T9N, R29E, S13, 24 June 1994, N. D. Atwood 20092 (holotype, BRY; isotypes, ARIZ, ASU, BRY, CAS, NMC, NY, OSC, UNM, US). Figure 6.

Phaeliae integrifoliae Torrey similis, sed herba pilis nigris capitato-glandularibus dense tecta, seminibus nigris alveolatis, $3-3.4 \times 1.2-2.5 \mathrm{~mm}$, in faciebus ambabus crislae ventralis excavatis, crista curva integra vel in latere altero leviter corrugata, superficie dorsali non profunde alveolatoverrucata differt.

Annual or biennial, scented, (1.5)3.1-5.1 dm tall; stems densely covered with short and long, black multicellular capitate-glandular and short nonglandular hairs, leafy, solitary with 3 to 5 lateral branches above the base. Leaves basal and cauline, densely short stipitate-glandular and hirsute-setose, lower leaves oblong-lanceolate, irregularly crenate-dentate or shallowly lobed, the lower petiolate, petiole to $2.2 \mathrm{~cm}$, upper leaves lanceolate, reduced upward, sessile to short-petiolate. Inflorescence of terminal secund racemes, densely capitate-glandular, setosehirsule, racemes 3 or 4 at the end of each branch, elongating to $1.5 \mathrm{dm}$ in fruit; calyx $2.5-3.3 \mathrm{~mm}$ in flower, to $6 \mathrm{~mm}$ in fruit, obovate, densely capitateglandular and hirsute, divided nearly to the base, ca. Iwice as long as the capsule; corolla tubular, 4.2-4.7 mm, lobes short, sparsely pubescent, pale lavender, fading white in pressed specimens; stamens and style exserted $4.5-5 \mathrm{~mm}$, the filaments glabrous, anthers blue, style bifid 2/3 its length, pubescent from the base to a little above the branching. Capsule $3.5-3.7 \mathrm{~mm}$, oval to oblong, glandular and setose; mature seeds oblong, black, 3-3.4 × 1.2-2.5 mm, excavated on both sides of the ventral ridge, alveolate, the ridge curved, entire to faintly corrugated on one side, dorsal surface shallowly alveolate-warty.

Etymology. Phacelia pinkavae is named in honor of the first collector of the species and student of the Arizona flora, Donald J. Pinkava at Arizona State University. His specimen was observed on a visit to ASU years ago, but the exact collection information is not currently available. It was collected north of Springerville, Arizona, and identified as P. integrifolia.

Relationships. Phacelia pintavae is similar to $P$. integrifolia but is distinct from this species in having the herbage densely covered with black capitate-glandular hairs and having black, oblong, alveolate seeds 3-3.4 $\times$ $1.2-2.5 \mathrm{~mm}$, excavated on both sides of the ventral ridge, the ridge curved, entire to a little corrugated on one side. and the dorsal surface shallowly alveolate-warty.

Distribution, habitat, and phenology. Phacelia pinkavae flowers from late May to August. It occurs in volcanic gravels, rocky talus slopes, pumice and andesite soils, grasslands, and grass-shrub communities sometimes with pinyon-juniper. It is associated with Pinus edulis, Juniperus monosperma, Gutierrezia sarolhrae, Mentzelia multiflora (Nultall) A. Gray, M. springeri (Standley) Tidestrøm, Brickellia eupatorioides (L.) Shinners, Chrysothamnus nauseosus, Gilia pinnatifida Nuttall ex A. Gray, Bouteloua Lagasca, Castilleja Mulis ex L. f., Yucca elata Engelmann, Verbascum thapsus L., and Opuntia whipplei Engelmann \& J. M. Bigelow at 6000-7594 ft. (1830$2300 \mathrm{~m}$ ) elevation in Apache County, Arizona, east to Santa Fe, Catron, and Sandoval counties, New Mexico. 


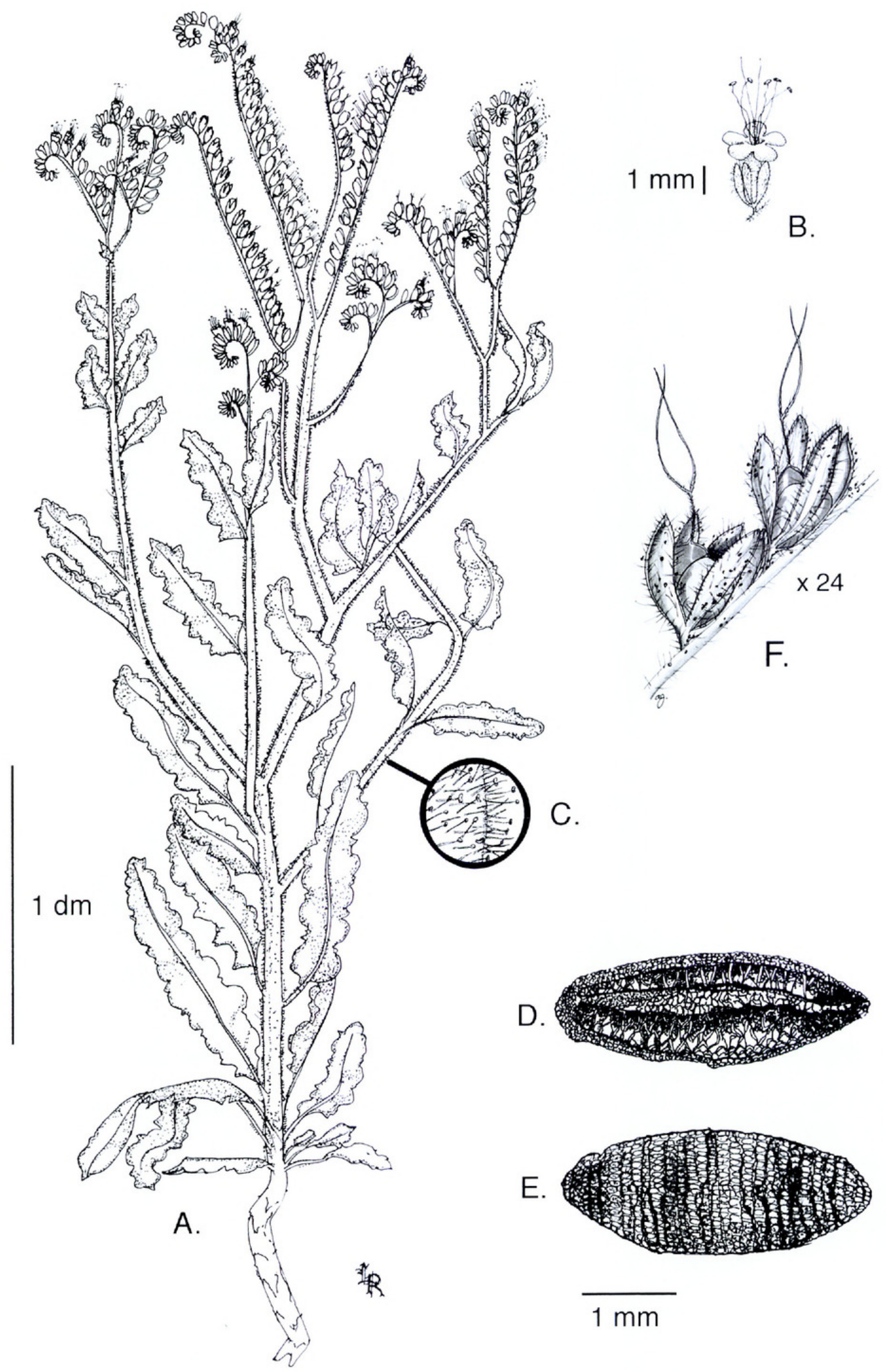

Figure 6. Phacelia pinkavae N. D. Atwood. - A. Plant. - B. Flower. - C. Stem pubescence. -D. Ventral seed surface. -E. Dorsal seed surface. -F. Fruit. Drawn from the isotype, N. D. Atwood 20092 (BRY). 
Conservation status. The Nature Conservancy global and state rarity ranking for this species should be G2S3, based on its range.

Paratypes. U.S.A. Arizona: Apache Co., ca. 5 mi. N of Concho along Hwy. 180 in gravelly soil, 22 May 1972, L. C. Higgins 5419 (BRY); betw. Concho and St. Johns, 22 May 1972, L. C. Higgins 5424 (BRY); just N of Springerville, 22 May 1972, L. C. Higgins 5425 (BRY); $5.2 \mathrm{mi}$. NE of Concho along Hwy. 61, 4 June 1974, N. D. Atwood 6155 (BRY); ca. 4 mi. W of Whiterock along Hwy. 4, 5 June 1974, N. D. Atwood 6216 (BRY); 30.1 mi. E of Jct. 60/61 on Route 60 W of Springerville in rolling grassland hills on dark volcanic soils, 15 June 1993, Jon P. Rebman 1890 (BRY); 14.9 mi. E of Jet. 60/61 on Route $60 \mathrm{~W}$ of Springerville in grasslandshrub community, 15 June 1993, Jon P. Rebman 1892 (BRY); 0.4 mi. S of Jcl. 191(666)/81 on Route 191(666) W of Lyman Lake and S of St. Johns, 12 July 1993, Jon P. Rebman \& G. Leake 1905 (BRY); T9N, R30E, S18 at jct. of Hwy. 180/ $60 \mathrm{~N}$ of Springerville in gravelly volcanics of shrub-grass community, 6 Sep. 1995, N. D. Atwood 20600 (ARIZ, ASU, BRY, CAS, NMC, NY, OSC, UNM); jet. of Hwys. 60/180 ca. 6.98 mi. $\mathrm{N}$ of Springerville, 6 June 2000, S. L. Welsh \& $M$. Ralphs 27666 (BRY); Catron Co., 66 mi. W of Socorro along Hwy. 60, 25 June 2002, L. C. Higgins 23798 (BRY, Dixie State College); just E of Datil, T2S, RIOW, S12SEI/4, 25 Aug. 2003, R. C. Sivinski 5762 (BRY); Catron Co., 66 mi. W of Socorro along Hwy. 60, 25 June 2002, L. C. Higgins 2.3798 (BRY). New Mexico: Sandoval Co., ca. 4 mi. W of Whiterock along Hwy. 4, 5 June 1974, N. D. Atwood 6216 (BRY); Santa Fe Co., Hwy. 4 near split ca. 5 mi. E of Los Alamos, T19N, R7E, S2I NW1/4; $3552.07 .3^{\prime} \mathrm{N}$. $10611.49 .3^{\prime} \mathrm{W}, 29$ June 2003, R. C. Sivinsti 5739 (BRY).

Acknowledgments. I especially appreciate the help of Lee E. Hughes, Bureau of Land Management Ecologist for the Arizona Strip District, for his support and help in securing financial assistance through the National Fish and Wildlife Foundation for conducting fieldwork on the Arizona Strip. This funding, and that provided by Brigham Young University and Lake Mead National Recreation Area, has allowed me to conduct fieldwork leading to a better understanding of the flora and the discovery of several new taxa. Appreciation is also expressed to Arnold Clifford. Navajo botanist, for extending a welcome hand and traveling with me on several collecting trips on the Navajo Reservation and elsewhere in New Mexico and Arizona. Randal V. Baker, Bean Museum graphics designer, scanned and prepared the illustrations for publication. Illustrations were prepared by Amelia Landes, April Jensen, and Liz Richards. I thank them for their valuable assistance. Appreciation is also extended to the reviewers, Richard Halse, Steven P. McLaughlin, and Victoria C. Hollowell. Latin for Phacelia pinkavae was translated by Kate McNeil and the 2001 Botanical Latin Class. The other Latin translations were kindly provided by Stanley L. Welsh.

Literature Cited

Atwood, N. D. 1975. A revision of the Phacelia Crenulatae group (Hydrophyllaceae) for North America. Great Basin Naturalist 35: 127-190.

2005. New species of Mentzelia (Loaceae) and Phacelia (Hydrophyllaceae) from New Mexico. W. N. Amer. Naluralist 65(3): 367-370.

Voss, J. W. 1937. A Revision of the Phacelia Crenulatae group. Bull. Torr. Bot. Club 64: 37: 81-96, 133-144. 


\section{$2 \mathrm{BHL}$ Biodiversity Heritage Library}

Atwood, N. Duane. 2007. "Six new species of Phacelia (Hydrophyllaceae) from Arizona and New Mexico." Novon a journal of botanical nomenclature from the Missouri Botanical Garden 17, 403-416. https://doi.org/10.3417/1055-3177(2007)17[403:SNSOPH]2.0.CO;2.

View This Item Online: $\underline{\text { https://www.biodiversitylibrary.org/item/41805 }}$

DOI: https://doi.org/10.3417/1055-3177(2007)17[403:SNSOPH]2.0.CO;2

Permalink: https://www.biodiversitylibrary.org/partpdf/17572

\section{Holding Institution}

Missouri Botanical Garden, Peter H. Raven Library

\section{Sponsored by}

Missouri Botanical Garden

\section{Copyright \& Reuse}

Copyright Status: In copyright. Digitized with the permission of the rights holder.

License: http://creativecommons.org/licenses/by-nc-sa/3.0/

Rights: https://biodiversitylibrary.org/permissions

This document was created from content at the Biodiversity Heritage Library, the world's largest open access digital library for biodiversity literature and archives. Visit BHL at https://www.biodiversitylibrary.org. 